Proc. Estonian Acad. Sci. Geol., 1998, 47, 1, 3-19

\title{
HOLOCENE HISTORY OF VEGETATION AND LANDSCAPE ON THE KÕPU PENINSULA, HIIUMAA ISLAND, ESTONIA
}

\author{
Lars-König KÖNIGSSON ${ }^{\mathrm{a}}$, Leili SAARSE ${ }^{\mathrm{b}}$, and Siim VESKI ${ }^{\mathrm{a}}$, b
}

\footnotetext{
${ }^{a}$ Institute of Earth Sciences, Quaternary Geology, Norbyvägen 18B, S-75236 Uppsala, Sweden; e-mail: lars-konig.konigsson@natgeog.uu.se

b Institute of Geology at Tallinn Technical University, Estonia pst. 7, EE-0001 Tallinn, Estonia; e-mail: saarse@gi.ee,veski@gi.ee
}

Received 24 October 1997

\begin{abstract}
The Kõivasoo area is partly covered by aeolian sands poor in nutrients. Sedimentation started here later than the immigration of Alnus and with Tilia as an important marker. The development of the area includes the time since the immigration of Alnus into Hiiumaa, but several hiatuses have been recorded. Kõivasoo is extremely poor in cultural landscape and therefore merely animal husbandry has been practised there with little agriculture. The curves for xerophyticheliophytic plants and cultural plants are not very rich but some increase in hemerophilous plants can be seen (favoured by human activities). An increase in charcoal dust is seen in Late Boreal, two in Early Atlantic and Late Atlantic, and one in Early Sub-Boreal times. The charcoal maxima occur together with expansions of xerophytic-heliophytic plants and hemerophilous plants like Artemisia, Chenopodiaceae, Asteraceae tubuliflorae, Pteridium, and Urtica. Supposedly they all grew in settlements, pathways, or clearances connected with the Late Mesolithic sites which are now excavated east of the Kõivasoo Bog.
\end{abstract}

Key words: pollen analysis, cultural history, archaeological development, Mesolithic settlements, landnam phase.

\section{INTRODUCTION}

Large islands in the Baltic Sea off the Estonian and Swedish coasts have long attracted the interest of botanists, geographers, and geologists. All islands show marginal conditions for plants, animals, and culture, and the marginality is both edaphic and climatic. 
The organic world is very special on the islands. Many of the local plants and animals are characterized as relict forms, when compared with the main distribution of the same species in arctic and subarctic environments, as well as in continental areas in the southeast of Europe or in the more oceanic regions in the southwest and west. Numerous questions about possible immigration routes within and across the Baltic basin have arisen and some of them have never been sufficiently explained.

Both the climatic and cultural development trends are better studied in edaphically marginal areas than in areas with a heavy cover of Quaternary deposits upon the bedrock. Marginal conditions characterize all these islands, however to a lesser or larger degree. Therefore the islands serve as valuable objects for the study of palaeoenvironmental changes.

A transect across the Baltic from the Danish island Funen via Öland and Gotland to Saaremaa and Hiiumaa, and farther to the Estonian mainland and east to Russia passes over several climatic zones, showing a west-east transition from more oceanic to more continental conditions. The palaeoenvironmental changes taking place along this profile during the Holocene might, because of the edaphic circumstances, describe the changing climatic conditions especially adequately, and we have assumed that even minor changes might have resulted in vegetation or environmental impacts quite promptly.

The present investigation of one bog-site on western Hiiumaa forms a part of a research along the profile actively studied since the middle of the 1960s and as a joint Estonian-Swedish project since 1971. Our aim is to apply detailed analysis techniques to material from the bog and to use new geological and archaeological information (Eltermann, 1993a, 1993b; Lõugas et al., 1995; Kriiska, 1995, 1996; Moora \& Lõugas, 1995; Raukas \& Ratas, 1995), palaeobotanical results, and accelerator mass spectrometer (AMS) ${ }^{14} \mathrm{C}$ dating as a basis for the reinterpretation of the results.

Hiiumaa Island (Dagö) is rather young in its present shape, though its highest parts emerged from the sea more than $10000 \mathrm{BP}$ according to the existing knowledge about land uplift. As we know, the only bog dating back to earlier ages is that of Kõivasoo on the Kõpu Peninsula (Fig. 1). It occupies a former lagoon basin and the possible time when it was isolated from the Baltic basin has long been debated (Kessel \& Raukas, 1967; Sepp, 1974; Ratas, 1976; Sarv, 1981; Sarv et al., 1982; Raukas \& Ratas, 1995).

The first pollen diagram from Kõivasoo was presented by Kents in 1939 (analysed by P. Thomson). It showed sedimentation of calcareous gyttja during the Late Boreal, succeeded by Carex peat growth in the Atlantic and onwards. Kessel elaborated a second pollen diagram which confirmed Kents's results (Kessel \& Raukas, 1967). Both diagrams were made in the mode of these times and were based upon tree pollen taxa only.

Kessel also studied the mollusc fauna at Kõivasoo and used the results to calculate a chronology of the isolation of the bog from the Baltic. According to 
Kents the Litorina Sea transgression limits reached $27.3 \mathrm{~m}$ a.s.1. on the Kõpu Peninsula. Thus, the Litorina Sea could have transgressed into the Kõivasoo basin (Kents, 1939). Kessel, who used also diatom analysis for her interpretation, did not accept this view. She suggested that the isolation occurred about 7000 BP (Kessel \& Raukas, 1967).

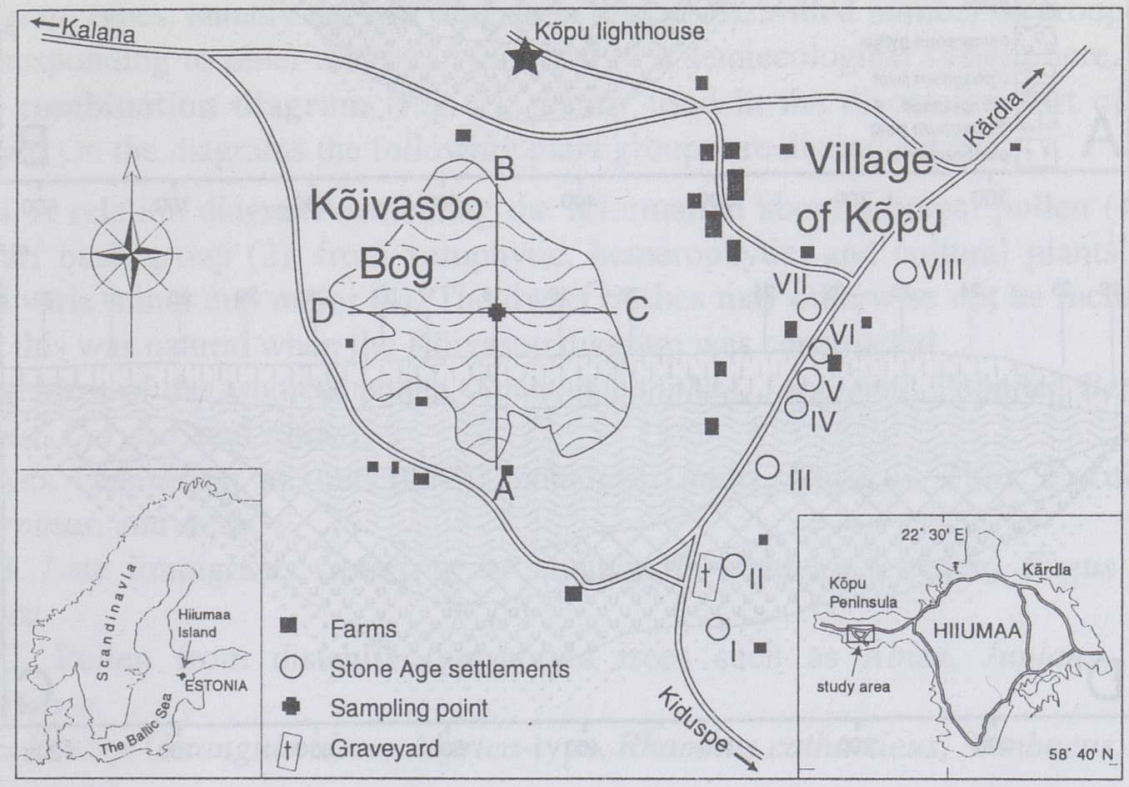

Fig. 1. The location of the Kõivasoo Bog, the Stone Age archaeological settlement sites, and the position of the investigated transects $\mathrm{A}-\mathrm{B}$ and $\mathrm{C}-\mathrm{D}$.

Sarv repeated the pollen study of the Kõivasoo deposits, added macrofossil analysis to the methods used, and first applied ${ }^{14} \mathrm{C}$ analyses to the stratigraphy (Sarv, 1981; Sarv et al., 1982). The results showed that the lagoon probably separated from the Baltic basin already during the Late Boreal and at least 8200 BP (Sarv et al., 1982).

Based on fieldwork, we placed Kents's sampling spot tentatively close to the margin of the bog. It roughly coincides with core 5 in our profiles (Fig. 2). The sampling spot of Kessel and Raukas would lie close to our core 7, while Sarv's core has probably been taken near our cores 9 and 10 . The position of the older cores has been decided on the basis of a correlation between the earlier reported stratigraphies and our profiles, and especially on the correlation with our depth figures of the contact between gyttja and calcareous gyttja (Fig. 2). 

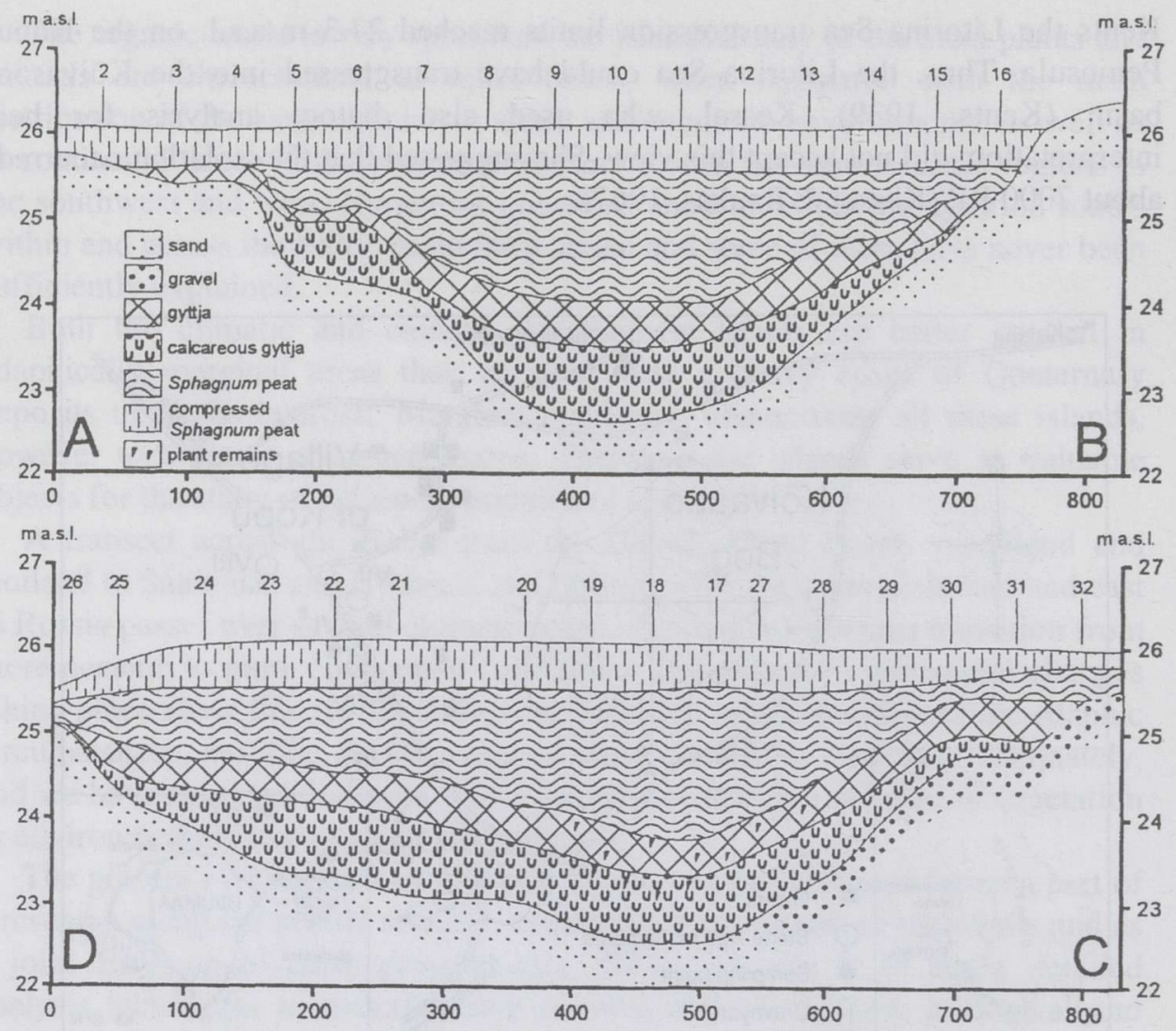

Fig. 2. Transects from the Kõivasoo Bog. For location see Fig. 1.

\section{METHODS}

Both the profiling and sampling were performed with a Belarus peat auger. Core 9, almost $3.5 \mathrm{~m}$ deep, was subsampled with an $1 \mathrm{~cm}$ interval. For geochemical investigations $2 \mathrm{~cm}$ thick samples were collected. These were dried at $105^{\circ} \mathrm{C}$ for 48 hours, weighed, and kept in an oven at $500^{\circ} \mathrm{C}$ for two hours, then weighed once more and heated at $825^{\circ} \mathrm{C}$. Finally the organic matter and carbonate contents were calculated (Fig. 3).

Pollen samples were prepared following standard methods. Samples containing minerogene particles were treated with HF according to Jørgensen (1963). Routine counting of the pollen grains was made at $\times 25$ magnification, using $\times 10$ oculars. Special determinations included phase contrast analysis at $\times 40$ or $\times 100$ magnification. No special measurements of larger grass pollen were made, nor were pore measurements practised. Pollen of Hordeum-type may then 
include barley, but might comprise millet pollen and some other large Gramineae as well. By all determinations the reference collection of the Department of Quaternary Geology at Uppsala University was used for comparison.

The pollen diagram was worked out mainly according to the ideas put forward by Königsson (Königsson, 1968; Königsson et al., 1995). Some of the ideas behind may be discussed and the decision of joining Picea and Fagus together in "the late immigrants" may well be debated. There are, further, two diagram types, namely the full diagram (Figs. 4-6), with a number of groupings corresponding to older diagram types and to a semiecological system here, and the combination diagram (Fig. 7), mainly used in the discussion part of the paper. On the diagrams the following plant groups are distinguished:

1-4. A relation diagram combining the information about arboreal pollen (1), a dwarf bush group (2), from xerophytic, hemerophytic, and cultural plants (3), and varia minor and major (4). The dwarf bushes may otherwise not be included but this was natural when the Kõivasoo diagram was constructed.

1 A. Most of the arboreal pollen (Salix, Hippophaë, Juniperus, Populus, Betula, Pinus, Corylus, and Alnus).

1 A:b. Quercetum mixtum (QM), including Ulmus, Quercus, Tilia, Fraxinus, Carpinus, and Acer.

1 B. Late immigrants (referring to situation in southern Sweden) Fagus and Picea.

1 C. Pollen from distantly transported trees such as Abies, Juglans, and Castanea.

1 E. Bushes (Frangula alnus, Myrica-type, Rhamnus catharticus, Sambucus, and Viburnum).

2. Dwarf bushes (Calluna, Betula nana, Empetrum-type, Ericaceae, Vacciniumtype). This group may include Ephedra too.

3 A:a and A:b. Xerophytic plants, minor and major. Since it has been important to follow the summary curve of the minor constituents and since the major constituents may dominate, we have chosen to divide these (and some further) curves in the one called "minor" and the one called "major".

3 B. Other terrestric plants.

3 C. Possibly cultivated plants (Avena-type, Cannabaceae, sometimes Cannabis and Humulus are distinguished, Fagopyrum-type, Hordeum-type, Linum usitatissimum, Triticum-type).

3 D:a and D:b. Hemerophilous plants, minor and major. Distinction according to Sterner (1938).

3 E. Terrestric spores.

4 A:a and A:b. Varia, minor and major.

5 A. Fen plants.

6 A. Aquatic plants.

7 A. Algae (Pediastrum, Botryococcus, Hystrix-Hystrichosphaeroid cysts).

8 A. Bryophyta. 


\section{A. Stomata.}

10 A. Charcoal.

11 A. Destruction degree.

12 A. Pollen sum.

13 A. Diversity.

\section{SITE DESCRIPTION}

Kõivasoo is a small raised bog in the southern part of the Kõpu Peninsula $\left(58^{\circ} 54^{\prime} \mathrm{N}, 22^{\circ} 12^{\prime} \mathrm{E}\right)$. It measures some $1120 \times 875 \mathrm{~m}$ and has a modern vegetation cover with pine trees, Sphagnum-species, and heather dominating. Coastal formations and bluffs of some Baltic prestages surround it. To the north is Mägipe Hill with Tornimägi that reaches an elevation of $66.2 \mathrm{~m}$ a.s.l. Dune sands lying westwards reach $45.2 \mathrm{~m}$ a.s.l.

\section{Geological setting and environmental conditions}

The Kõpu area has an Ordovician substratum, mainly consisting of limestone. The overburden is characterized by glacial, glaciofluvial, marine, and aeolian deposits, the thickness of which amounts to some $82.7 \mathrm{~m}$ (Eltermann, 1993a). Mägipe Hill with Tornimägi is supposed to be of glacial, mostly erratic origin (Eltermann, 1993a, 1993b). The hill is surrounded by different beach formations of various Baltic prestages (Kents, 1939; Kessel \& Raukas, 1967; Raukas \& Ratas, 1995).

Ancylus Lake formations are located at levels between 30 and $45 \mathrm{~m}$ a.s.l., Litorina deposits at 15.5-27 m a.s.l. (Kents, 1939). New measurements of the terraces and bluffs have also shown levels of 30-40 $\mathrm{m}$ a.s.l. on the northern slope of the hill and 27-35 m a.s.l. on the southern slope (Eltermann, 1993b).

About $60 \%$ of the island is covered by pine, birch, and spruce woodlands, swampy thickets, and juniper shrubbery (Sepp, 1974; Saarse, 1994). Arable land makes up less than one-fourth of the territory and occurs in coastal areas and around villages. The flora is rich, with about 1000 species of higher plants and 50 rare species that are under protection (Sepp, 1974). Pine-spruce-birch forest and sandy heaths rich in lichens as Cladonia (Rebassoo, 1967) form c. $70 \%$ of the Kõpu Peninsula. The number of rare species, mainly Sub-Atlantic and Mediterranean ones (Taxus baccata, Hedera helix, etc.), is around 80 .

At the beginning of historic times Hiiumaa was rather sparsely populated and used as the Saaremaa hinterland for hay making and timber cutting (Sepp, 1974; Ratas, 1976). According to Johansen (1951), Hiiumaa was permanently settled in the 13th century. However, the central part of the island stayed almost unsettled throughout the medieval period. By the 19th century, 13 estates and numerous farms owned and cultivated all suitable land. Forest cutting was very intense during the 16th-18th centuries, because the Kõpu lighthouse, Kärdla cloth mill, 
and building of Tallinn and Paldiski harbours needed timber. This caused a drastic decrease in the forest area and the migration of coastal dunes, especially on the Kõpu Peninsula (Tiismann, 1924). Owing to large-scale amelioration, the area of meadows and arable land has increased up to $30 \%$ during the last 40 years.

\section{Archaeological remains}

The village of Kõpuküla is rich in prehistoric monuments (Lõugas et al., 1995). The oldest finds are the Stone Age hearths on Ancylus and Litorina beach ridges, charcoal of which is dated to $6755 \pm 50 \mathrm{BP}$ (Tln-2016) and $6640 \pm 60 \mathrm{BP}$ (TA-2533) (Kriiska, 1996). More than 10 stone-cist graves have been identified, dating back to the Iron Age (Lõugas, 1981). One iron melting place and several stone heaps in the forest nearby have been excavated (Lõugas, 1981). They might derive from the Iron Age and mark an ancient field system.

\section{RESULTS AND INTERPRETATION}

\section{Lithostratigraphy}

We investigated the morphology and sediment stratigraphy of the Kõivasoo (Bog) Lagoon along two transects (Fig. 2). They show that the bottom topography of the bog is uneven, with terrace-like surfaces in the southern and eastern parts of the basin between the heights of 24-25 $\mathrm{m}$ a.s.l. The basal sediment is sand with plant remains in the deeper part of the basin and gravel on the slopes. It is covered by a calcareous unit, which on the lithological transects is shown as calcareous gyttja. Along the west-east transect (Fig. 2, D-C) the thickness of this unit is rather uniform, about $1 \mathrm{~m}$, on the south-north transect (Fig. 2, A-B) the thickness varies, but does not exceed $0.90 \mathrm{~m}$. Calcareous gyttja is covered by gyttja, which imprints the bottom topography of the basin with a total thickness of about $0.5 \mathrm{~m}$. The lowermost gyttja unit is enriched with mollusc shells, the uppermost with plant detritus. Between them is an algaegyttja bed. In Fig. 2 the lithology on the transects is simplified and different gyttja beds are indicated as one gyttja layer. The contact between the calcareous gyttja and gyttja is sharp and in some places paved with huge amounts of mollusc shells and thin sand lamina (Fig. 2, cores 17-19).

The lacustrine deposits are covered with peat, represented mostly by Sphagnum peat. A detailed description of the deposits is given below. The sediment composition is displayed in Fig. 3 and it shows one soil erosion period about 4400 years ago at the level of $125.5-126.5 \mathrm{~cm}$. 


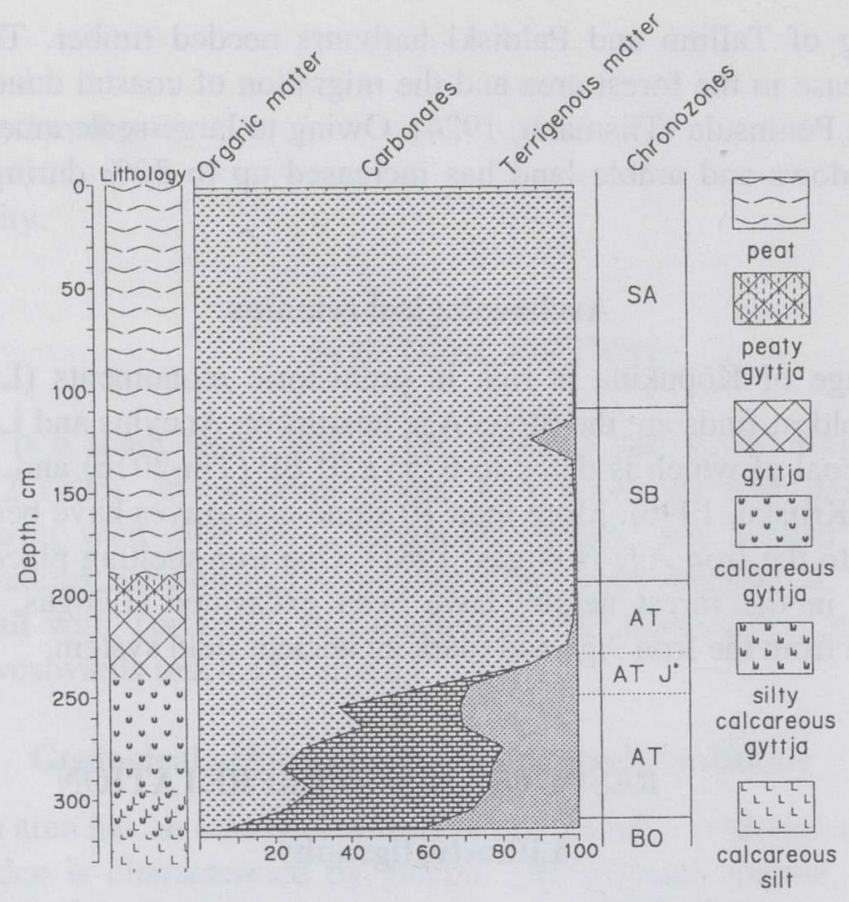

Fig. 3. Sediment composition of the Kõivasoo Bog (core 9).

\section{Lithostratigraphy of the monolith}

The monolith is described in the pollen diagram as a subdivision of peat underlain by gyttja, calcareous gyttja, downwards silty, and silt with some calcareous gyttja and mollusc remains (Figs. 1, 2, core 9). The general characterization of the deposits is given using the Troels-Smidt (1955) system. The lithology is simplified in Figs. 2-7.

A. $344-318 \mathrm{~cm}$ : calcareous silt with shell fragments. At $340 \mathrm{~cm}$ clay layer. Bands and black spots, which might be FeS or heavy minerals as magnetite. Formula: $A g$ 3, $L c 1,(\alpha+\beta)+$. The core continued in underlying sand or silt.

B. $318-295 \mathrm{~cm}$ : banded grey calcareous gyttja with shades in olive green (algae remains), silty. At 300 and $314 \mathrm{~cm}$ tendencies of $\mathrm{FeS}$ spots or restricted bands. Upper limes indeterminable. Formula: $L c 4$.

C. 295-291 cm: olive-grey, partly with black spots calcareous gyttja. Clear cyclotheme structure, but not in bands. Shell fragments. Upper limes $\pm 1 \mathrm{~mm}$.

D. 291-283 cm: light grey calcareous gyttja, almost without cyclothemes. Upper limes 1-5 mm. Formula: $L c 4$.

E. 283-276 cm: yellowish grey calcareous gyttja with dark spots or points of FeS or organic. Upper limes $\pm 1 \mathrm{~mm}$. Formula: $L c 4, A g(+)$.

F. 276-267 cm: light grey calcareous gyttja with some Characeae peat detritus in cyclothemic structure. Upper limes $1 \mathrm{~mm}-1 \mathrm{~cm}$. Formula: $L c 4$. 
G. 267-256 cm: yellowish grey calcareous gyttja with darker bands, possibly with algae remains. Upper limes $1 \mathrm{~mm}-1 \mathrm{~cm}$. Formula: $L c 4, A g(+), T h^{2}++$.

H. 256-246 cm: yellowish grey calcareous gyttja with obvious cyclotheme structures. Scattered plant and shell fragments, some silt. Upper limes unknown. Formula: $\operatorname{Lc} 4, A g(+), T h^{2}(+)$.

I. 246-240.5 cm: light grey calcareous gyttja with plant detritus, shells and shell fragments of Pisidium sp., Bithynia sp., Limnaea ovata. Small sand lenses, some in situ Characeae; they should be considered as thin peat fragments, sedentary grown. Upper limes $\pm 1 \mathrm{~mm}$. Formula: $L c 3, A g++, \alpha+\beta,(\alpha+\beta)+$.

J. 240.5-234.4 cm: greyish olive-brown homogeneous fine-grained gyttja, with small lenses of silt and plant detritus. Upper and lower limes $\pm 1 \mathrm{~mm}$. Formula: $L d^{2} 1, L c 2, A g 1, T h^{2}+$.

K. 234.4-227 cm: olive-grey fine-grained gyttja with a $0.4 \mathrm{~mm}$ silt layer between 234-234.4 cm. Abundance of plant detritus. Both upper and lower limes $\pm 1 \mathrm{~mm}$. Formula: $L d^{2} 1, L c 2+, A g+, T h^{2}++$.

L. 227-211.5 cm: yellowish grey, quite homogeneous fine-grained gyttja, downward with silt and plant detritus. Upper limes $\pm 1 \mathrm{~cm}$. Formula: $L d^{2} 1, L c 2, A g 1, T h^{2}+$.

M. 211.5-208 cm: pink-coloured algae gyttja with peat detritus in the uppermost part, homogeneously fine-grained, sandy. Upper limes $\pm 1 \mathrm{~mm}$. Formula $L d^{2} 3, A g 1, T h^{2}+$. N. 208-201 cm: yellowish brown peat detritus and sand containing gyttja. Upper limes $>1 \mathrm{~cm}$. Formula: $L d^{2} 2, T h^{2} 2, A g+$.

O. 201-197 cm: dark brown gyttja containing peat. Upper limes invisible. Formula: $L d 3, T h^{3} 1$.

P. 197-190 cm: dark brown peat, probably with gyttja admixture. Contains Eriophorum stands. Upper limes $>1 \mathrm{~cm}$. Formula: $T b^{3} 1, T h^{3} 1-2, L d 2, L c+$.

Q. 190-180 cm: yellowish brown Sphagnum peat. Contains a lot of other peat detritus and might have been formed in the telmatic zone just around the water level. Upper limes $\pm 1 \mathrm{~mm}$. Formula: $T b^{2} 1, T h^{2} 3$.

R. 180-179 cm: blackish Sphagnum peat, decomposed or with charcoal. Upper limes quite sharp, $\pm 1 \mathrm{~mm}$. Formula: Sh 4 ?

S. $179-163 \mathrm{~cm}$ : lightly yellowish grey-brown heterogeneous Sphagnum peat with abundant peat detritus. Might be an admixture with a telmatic peat or limnic peat of Phragmites or Typha types. Upper limes $>1 \mathrm{~cm}$. Formula: $T b^{3} 3, T h^{3} 1$.

T. 163-148 cm: brownish fine-grained Sphagnum peat with Eriophorum rests and some wood fragments. Upper limes $>1 \mathrm{~cm}$. Formula: $T b^{3} 3++, T h^{1}++$.

U. 148-126.5 cm: brownish Sphagnum peat with Eriophorum rests and some wood fragments. Quite sharp upper limes, about $\pm 1 \mathrm{~mm}$. Formula: $T b^{3} 4, T h^{1}+, T l+$.

V. 126.5-125.5 cm: black layer, fine-grained, probably Sphagnum peat with sand and charcoal. Sharp upper limes $<0.5 \mathrm{~cm}$. Formula: $S h 4, T h^{1}+$.

X. 125.5-98 cm: fine-grained greyish brown homogeneous Sphagnum peat with some Eriophorum stands. A few rootlets still penetrate the deposits down to this level. No visible upper limes. Formula: $T b^{4} 4, T h+$. 
Y. 98-77 cm: greyish compact homogeneous Sphagnum peat with occasional wood fragments. Formula: $T b^{4} 4, T h+, T l+$.

Z. $77-49 \mathrm{~cm}$ : dark brown to blackish brown homogeneous highly humified Sphagnum peat with few rootlets. No visible upper limes. Formula: $T b^{4} 4, T h^{4}+$. AA. 49-36 cm: slightly browned but still completely homogeneous, decomposed Sphagnum peat with remains of Eriophorum stands. Upper limes $>1 \mathrm{~cm}$. Formula: $T b^{3} 3, T h^{3} 1$.

AB. $36-0 \mathrm{~cm}$ : dark brown to blackish brown highly humified Sphagnum peat with rootlets, especially in the uppermost part. Formula: $T b^{3} 3, T h^{3} 1$.

\section{Pollen analysis}

Two parts, an upper with low tree pollen and a lower with considerably higher arboreal pollen values characterize the pollen diagram (Fig. 4). Pollen of Quercetum mixtum (QM) increases in the middle of the section. Picea pollen increases in the uppermost parts. Pediastrum and Botryococcus and some Hystrichosphaeroid cysts dominate in the lower section (Fig. 6), while the transition to the Sphagnum dominated peat shows an intermediate sedimentation of Cyperaceae, Equisetum, Gramineae, and Polypodiaceae together with pollen of fen plants and aquatics (Fig. 5).

Alnus ranges through the whole diagram while Tilia starts when the amount of QM increases. The Tilia limit is then present in the diagram, but the lower parts of it show low percentages as does QM as a whole. The pollen diversity increases upward and a number of culminations of the charcoal dust occur in the lower parts of the diagram.

Pollen of dwarf bushes is abundant in the upper section especially Calluna, Ericaceae, and the Vaccinium-type. There are also signs of hiatuses in the curve for the dwarf bushes and two pronounced minimums in the Calluna curve which need attention.

As said above, Alnus is present in the whole diagram while Tilia starts well below the transition between the calcareous gyttja and gyttja (Fig. 4). According to Jørgensen (1954), the QM constituents may reach a certain level where the QM collective curves obtain an Atlantic "standard" and which is ultimately dropping together with the Ulmus decline. This level (Jørgensen's zone VII) marked as AT J* in Figs. 4-7 is reached a little later and may indicate the start of "true" Atlantic conditions.

The first drop in the Ulmus curve appears well below the transition into the peat, before what has been judged to be the real Ulmus decline (Fig. 4). This may have had a similar background as suggested for the Pitkasoo Mire on Saaremaa (Saarse \& Königsson, 1992), namely that there might have been an earlier drop in the QM curve because of an earlier land-use (combined with a slight rise in the Pinus curve). The final diminishing of Ulmus is then related to a later drop in the QM curve which happened already before the landnam phase sensu stricto. Apart from the mentioned increase in the Pinus curve, however, no other signs 
may be seen, neither in the Juniperus curve nor in the curves of xerophytic or hemerophilous plants.

\section{Chronology}

Two sets of radiocarbon dates have been obtained from the Kõivasoo Bog. Samples for the first set were taken by Sarv and Ilves (Sarv, 1981) about $50 \mathrm{~m}$ north from our main core (near our core $9-10$, Fig. 2) and analysed at the ${ }^{14} \mathrm{C}$ laboratory of the Institute of Zoology and Botany, Tartu (laboratory index TA in the table). The bulk organic matter or carbonate fraction was used for datings. The depth adjustment with our core is based on the correlation of the stratigraphical borders and the results of pollen analyses. The second set of samples for AMS dating was taken from our main monolith (core 9) and analysed at the Angström Laboratory, Department of Ion Physics, Uppsala (laboratory index $\mathrm{Ua}$ in the table). At the depths of 36 and $140 \mathrm{~cm}$ a piece of wood was analysed, at 241 and $289.5 \mathrm{~cm}$ plant fragments were washed out and chemically pretreated using the normal acialkali-acid method (Königsson et al., 1995; Possnert, 1990). Wood as terrestrial material was a good object for dating, however, the date $2775 \pm 65$ seems too old. The plant fragments washed out from the calcareous gyttja are more problematic in this respect, especially the date $8495 \pm 85$ (Ua-12 070), which does not match with the pollen stratigraphy. Other dates, even the uppermost date $1060 \pm 60 \mathrm{BP}$, resulted from different radiocarbon techniques fit with the pollen stratigraphy, as the bog today is heavily drained and the uppermost peat is thus thought to have gone through oxidation and compression. This suggestion is also supported by the nonexisting Secale curve, confirming the changes in the upper part of the sediment column.

Results of radiocarbon dates from the Kõivasoo Bog

\begin{tabular}{c|c|c|c|l}
\hline Depth, cm & $\begin{array}{c}\text { Adjusted } \\
\text { depth, cm }\end{array}$ & ${ }^{14}$ C age, BP & Laboratory No. & Material \\
\hline Core 9 & \multicolumn{3}{c}{} & \\
36 & & $2775 \pm 65$ & Ua-12073 & Wood \\
140 & & $4615 \pm 70$ & Ua-12072 & Wood \\
245.5 & & $6825 \pm 85$ & Ua-12071 & Plant fragments \\
289.5 & & $8495 \pm 85$ & Ua-12070 & Plant fragments \\
Sarv, 1981 & & & & \\
$0-10$ & $0-10$ & $1060 \pm 60$ & TA-523 & Bulk organic \\
$50-60$ & $65-75$ & $2440 \pm 60$ & TA-524 & Bulk organic \\
$100-110$ & $110-120$ & $4360 \pm 60$ & TA-525 & Bulk organic \\
$180-190$ & $185-195$ & $4860 \pm 70$ & TA-526 & Bulk organic \\
$200-210$ & $215-225$ & $6580 \pm 60$ & TA-527 & Bulk organic \\
$220-230$ & $245-255$ & $7440 \pm 60$ & TA-528 & Carbonate fraction \\
$230-240$ & $260-270$ & $7850 \pm 70$ & TA-529 & Carbonate fraction \\
$270-280$ & $315-325$ & $8190 \pm 90$ & TA-530 & Carbonate fraction
\end{tabular}




\section{DISCUSSION}

\section{Interpretation of pollen diagrams}

There are two culminations in the xerophytic plants, one during the Late Boreal, the other during the Sub-Atlantic (Fig. 5). In the first case Artemisia and Juniperus (and Populus) dominate while Artemisia and some Plantago lanceolata dominate in the upper Sub-Atlantic part. Apart from Artemisia and Juniperus, only few other constituents are present. This might be expected as a large portion of the Kõpu Peninsula is covered with considerably thick aeolian material, till, and glaciolacustrine deposits, which is not a favourable environment for xerophytic plants. They may have grown in the nearshore zone of former Kõivasoo Lake.

This is unfortunately also the case with the (possibly) cultivated plants which are dominated by Gramineae $>40 \mu \mathrm{m}$ and with few pollen grains of the Avena-type and very few of the Hordeum-type. The Avena pollen is perhaps a more reliable cultural indicator as Gramineae $>40 \mu \mathrm{m}$ may very well include pollen from Elymus and Glyceria species too.

The two hemerophilous curves describe better the cultural pollen flora and the hemerophilous major group seems to include more useful information. Especially the curves for Gramineae and Artemisia contain such information and the amount of Gramineae pollen increases in connection with the interpreted Late Mesolithic human impact (just prior the elm decline).

The terrestric spores occur merely in the lower half of the diagram. This is especially true for Lastrea dryopteris which is the most common in the calcareous gyttja part and in the silt.

The varia pollen curves are abundant in two parts of the diagram in and along the transition between the gyttja and the peat, and especially in the lowermost parts of the peat. The part varia major shows particularly well the succession from the lake conditions to the peat. Another impressive succession is from the Polypodiaceae into a beginning reed formation (possibly Phragmites), followed by an increase in Equisetum spores (in two parts) and finally the appearance of Cyperaceae (Carex) pollen. In the peat proper the Sphagnum spores increase the share of the varia major sum. There are three pronounced maxima in the occurrence of spores.

The fen plants are merely present in the gyttja and there is also a succession seen as a change from the Typha angustifolia/Sparganium-type into a Typha latifolia and a Menyanthes phase, which can be described as a successive overgrowth situation.

The aquatic plants as well show a succession with Potamogeton species in the lake phase and Nymphaea in the gyttja, when the lake was certainly overgrowing.

The algae curves show interference between Botryococcus and Pediastrum. They act controversially in the way that Botryococcus dominates in the 
calcareous gyttja part while Pediastrum does so in the nutrient-rich lower (lagoon) silt and gyttja during the period of overgrowth.

The graph for diversity is quite low in the lower (Boreal) parts of the diagram but increases together with the immigration of Tilia. Diversity is intermediate during the Atlantic, which could be expected, but is still low during what has been interpreted as Sub-Boreal. It is especially high in the second half of the Sub-Atlantic (starting $c .70 \mathrm{~cm}$ below the peat surface).

The charcoal dust curve is particularly interesting. There are usual high peaks in the lower parts of the stratigraphy. Four high peak areas are recorded. The first impressive peak appears in the Late Boreal. Two peaks occur in the Atlantic in connection with the Tilia immigration (both at the "tail" and together with the final rise according to Jørgensen, 1954), which would indicate the entrance of the true Atlantic conditions. The third peak is connected with what is interpreted as the elm decline. All these peaks occur together with an increase in some of the heliophilous-xerothermic curves like Gramineae $>40 \mu \mathrm{m}$, Chenopodiaceae, Artemisia, Asteraceae tubuliflorae, Pteridium, and Urtica (which is nitrophilous). They all may be interpreted as favoured by man in connection with the establishing of temporary or periodical settlements, pathways, or clearances.

\section{The stratigraphy and pollen diagram}

The zonation of the pollen diagram has to be judged against different sedimentologic events, especially when comparing the limits between different strata. The limit between the gyttja and the peat is almost continuous (above $1 \mathrm{~cm}$ ) but there are different strata within the peat and in the gyttja possessing sharp limits. The following layers have sharp upper limits: V $-125.5 \mathrm{~cm}, \mathrm{U}-$ $126.5 \mathrm{~cm}, \mathrm{R}-179 \mathrm{~cm}, \mathrm{Q}-180 \mathrm{~cm}, \mathrm{M}-208 \mathrm{~cm}, \mathrm{~K}-227 \mathrm{~cm}, \mathrm{~J}-240.5 \mathrm{~cm}, \mathrm{E}-$ $276 \mathrm{~cm}$, and $\mathrm{C}-291 \mathrm{~cm}$.

The black and fine-grained layer with charcoal and sand between 125.5 and $126.5 \mathrm{~cm}$ has sharp upper and also rather sharp lower limitation. It was formed due to the human impact or because of the fires in the bog and the surrounding forest, which caused wind-blown sand to be carried into the bog. Hiatuses might be calculated to have formed there, both on its upper and lower borders and within the layer proper. This level is also a turning point in the peat increment. Upwards it decreased considerably. Another such layer has been observed between 179 and $180 \mathrm{~cm}$ below the peat surface. It was described in the field as either completely decomposed Sphagnum peat or a charcoal layer. Both limitations are sharp and the pollen curves suggest that there are hiatuses included in this layer.

The transition between the detritus gyttja and gyttja containing peat happens at $190 \mathrm{~cm}$. The uppermost part is without silt, but at $208 \mathrm{~cm}$ is a very thin and well-defined minerogenic layer. This minerogenic layer might then be interpreted as a separate short sedimentological event or as representing extremely heavy rains or rainstorms or as a sign of temporary ingressive 
movements from the Baltic. Below the layer the transition continues with jelly algal gyttja. The silty part of the gyttja continues downwards to $267 \mathrm{~cm}$ where the silt disappears completely, but it reappears in the lowest parts.

According to radiocarbon dates calcareous gyttja possibly accumulated 8200$6800 \mathrm{BP}$, gyttja $6800-5300 \mathrm{BP}$, and peat started to deposit from $5300 \mathrm{BP}$ onwards. These dates are tentative, as there are lags in the sediment profile of unknown duration.

\section{The pollen diagram and the archaeological development}

Eight Stone Age sites have been found lately and they all are situated along the eastern shore of the Kõivasoo embayment-lake-fen-peatbog (Kriiska, 1996; Fig. 1). The settlement history extends into the Late Mesolithic (Kriiska, 1995, 1996). It seems quite possible that the settlement history may date back into the Late Boreal and Atlantic times according to the results and interpretations of the Kõivasoo Bog site. All the mentioned events with heliophytic-xerophytic or nitrophilous plants accompanying the charcoal dust peaks in the Early and MidAtlantic can very well be interpreted as signals of land occupation during these periods. The archaeological excavations at Kõpu sites I and IV displayed a lot of finds and charcoal pieces from the fire-pits which at site IV dated to $6755 \pm 50$ (Tln-2016) and $6640 \pm 60$ BP (Tln-2533; Kriiska, 1996). The Kõpu VIII settlement site, also rich in artefacts, was obviously founded about 500 years later. The find material and radiocarbon dates suggest that the first inhabitants came to the Kõpu Peninsula already during the Late Mesolithic (site I; Kriiska, 1995). Obviously they were seal hunters, as the osteological material consists mostly of bones of ringed seal (Lõugas et al., 1995; Moora \& Lõugas, 1995). Unfortunately the Stone Age habitation of the seal hunters at Kõpu falls into the period when the former lake at Kõivasoo began to overgrow, producing much local pollen and thus hampering the distribution and representation of pollen from dryer areas. This is especially true when talking about the nonlocal nonarboreal pollen and diversity. The discussed pre-elm decline in the Ulmus curve around $5000 \mathrm{BP}$ could be of anthropogenic origin.

\section{The development of the landscape on the Kõpu Peninsula}

The wind-blown sands of the Kõpu Peninsula seem to have been a dominating part of the environment for a long time. It is likely that the sand started to accumulate quite early since no obvious sand horizons have been included in the Kõivasoo stratigraphy. There are, however, some minor sand layers included in the profile (unit $\mathrm{V}, 125.5-126.5 \mathrm{~cm}$ ), and the lowermost silty part contains some sand and also shells and might have developed in a shore phase. The contact of calcareous gyttja and gyttja is sharp and paved by huge amounts of mollusc shells near the central part of the basin (around cores 17-19). This might indicate the lake-level rise and the changes in ecological conditions 
Kôivasoo Bog, full diagram - part 1

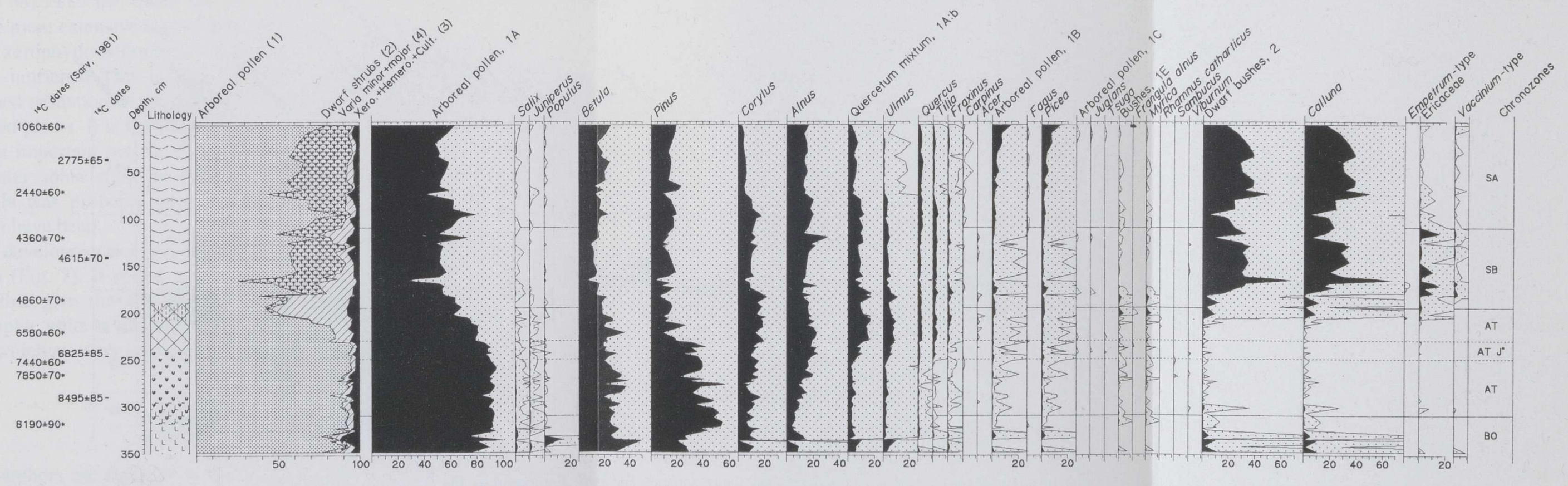

Fig. 4. Full pollen diagram of the Kõivasoo Bog (core 9). Part 1 - arboreal pollen and dwarf bushes. J" is the "true Atlantic" in the sense of Jørgensen, 1954 . For legend see Fig. 3.

Kôivasoo Bog, full diagram - part 2

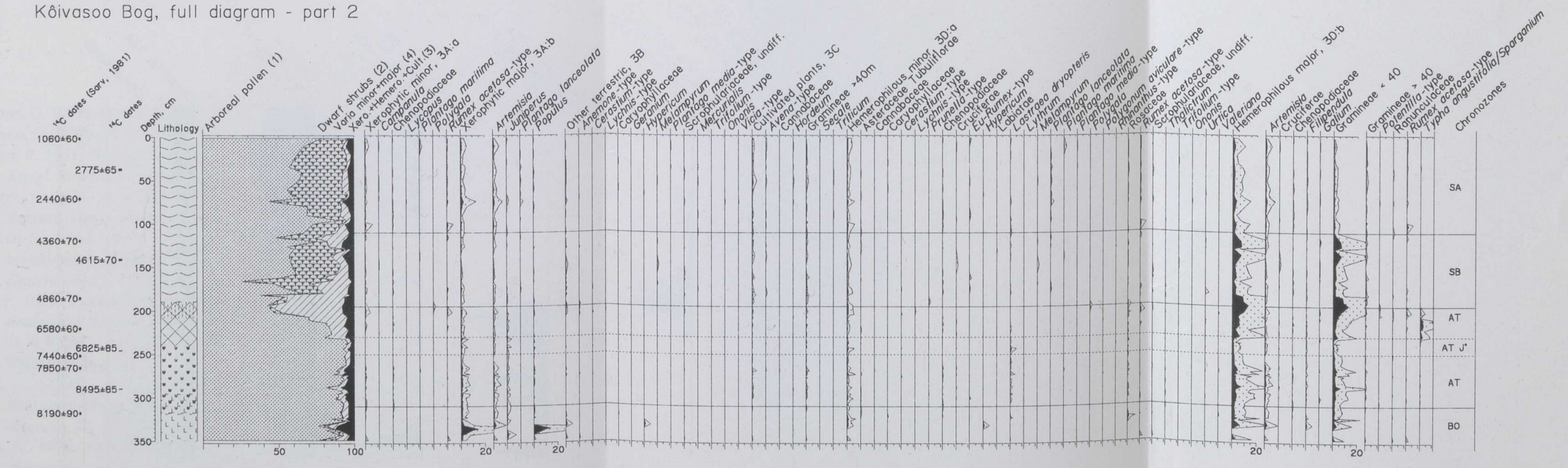

Fig. 5. Full pollen diagram of the Kõivasoo Bog (core 9). Part 2 - terrestrial nonarboreal pollen. For legend see Fig. 3. 
Kôivasoo Bog, full diagram - part 3

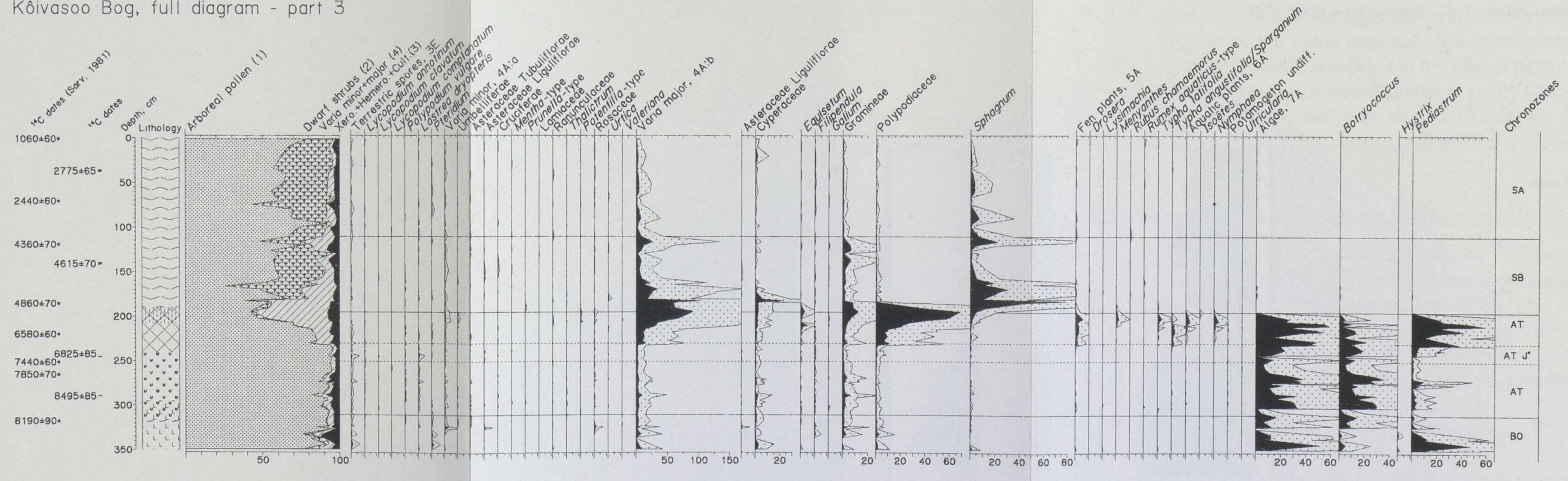

Fig. 6. Full pollen diagram of the Kõivasoo Bog (core 9). Part 3 - varia, fen plants, aquatıcs, and algae. For legend see Fig. 3.

Kôivasoo Bog, combination diagram

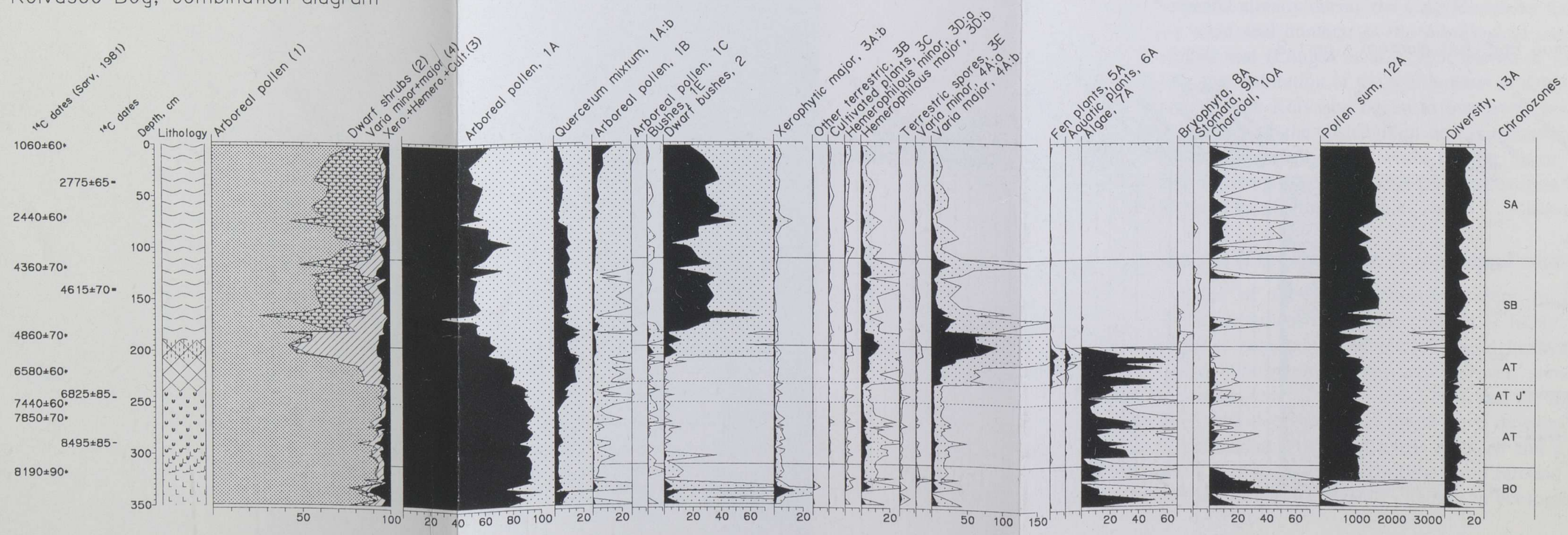

Fig. 7. Combination diagram of the Kõivasoo Bog (core 9). For legend see Fig. 3. 
dated to $6825 \pm 85 \mathrm{BP}$. There are also several hiatuses identified, some of which can hide more extensive lags of sedimentation.

The xerophytic-heliophytic curves are low, since the sand layers are very poor in nutrients. This is also probably one of the reasons, apart from the mentioned oxidation of the peat surface, for such a modest representation of the cultivated plants. It is therefore likely that hunting-fishing-gathering culture was the most important way to survive during long times, at least during the Stone Age. Later some signs of pastoral economies can be traced, but the Kõpu Peninsula was probably never cultivated in the same way as other parts of Hiiumaa have been.

The development of the Kõivasoo area is summarized in the combination diagram (Fig. 7). It shows most of the appearances, especially the tree pollen curves that give the chronological order. We have also introduced different stratigraphic units in the lithostratigraphic column, and particularly the thin peat layers, which are very important for the interpretation of diagram.

\section{ACKNOWLEDGEMENTS}

The authors are thankful to Dr. Göran Possnert, Uppsala University, for the AMS dates. We are also indebted to Prof. Anto Raukas, Institute of Geology, Tallinn, and Kersti Kihno, Institute of History, Tallinn, for valuable comments on the manuscript. The investigations were financially supported by the Estonian Science Foundation grant No. 1958.

\section{REFERENCES}

Eltermann, G. 1993a. Mandriliustiku hääbumine Lääne-Eesti saartel. Eesti Loodus, 5-6, 218-219.

Eltermann, G. 1993b. Hiiumaa geoloogi pilguga. Eesti Loodus, 3, 103-105.

Johansen, P. 1951. Nordische Mission, Revals Gründung und die Schweden-siedlung in Estland. Kungl. Vitterhets Historie Antikvitets Akademiens Handlingar, 74. Stockholm.

Jørgensen, S. 1954. A pollen analytical dating of Maglemose finds from the bog Aamosen, Zealand. Danm. Geol. Unders., II, 80. København.

Jørgensen, S. 1963. Early Postglacial in Aamosen. I. Geological and pollen-analytical investigations of Maglemosian settlements in the West-Zealand bog Aamosen. Danm. Geol. Unders., II, 87. København.

Kents, P. 1939. Postglatsiaalsed Läänemere rannajoone võnkumised Eestis illustreeritud Kõpu poolsaarel. Käsikiri. Eesti Teaduste Akadeemia Keskarhiiv.

Kessel, H. \& Raukas, A. 1967. The Deposits of Ancylus Lake and Littorina Sea in Estonia. Valgus, Tallinn (in Russian).

Kriiska, A. 1995. Archäologische Ausgrabungen auf dem Standort der ehemaligen Steinzeitsiedlung Kõpu I (Ristipõllu). Proc. Estonian Acad. Sci. Humanities and Social Sciences, 44, 4, 410-416.

Kriiska, A. 1996. Archaeological studies on the Kõpu Peninsula. Proc. Estonian Acad. Sci. Humanities and Social Sciences, 45, 4, 398-409. 
Königsson, L.-K. 1968. The Holocene history of the Grand Alvar of Öland. Acta Phytogeographica Suecica, $\mathbf{5 5}$.

Königsson, L.-K., Possnert, G. \& Atanassova, J. 1995. Construction and publication of diversified polien records - a practical and economical dilemma. PACT, 50, 497-507.

Lõugas, L., Kriiska, A. \& Moora, H. 1995. Coastal adaption and marine exploitation of the Island Hiiumaa, Estonia, during the Stone Age with special emphasis on the Kõpu I Site. PACT, 50, 197-211.

Lõugas, V. 1981. Täiendusi Hiiumaa muinasajaloole. Nõukogude Hiiumaa, 91, 93.

Moora, H. \& Lõugas, L. 1995. Natural conditions at the time of primary habitation of Hiiumaa Island. Proc. Estonian Acad. Sci. Humanities and Social Sciences, 44, 4, 472-481.

Possnert, G. 1990. Radiocarbon dating by the Accelerator Techniques. Norwegian Archaeological Review, 23, 1-2, 30-37.

Ratas, U. 1976. On the formation of the landscape of Hiiumaa island and its surrounding islets. In Estonia. Regional studies (Merikalju, L., ed.). Valgus, Tallinn, 104-113.

Raukas, A. \& Ratas, U. 1995. Holocene evolution and palaeoenvironmental conditions of Hiiumaa Island, northwestern Estonia. PACT, 50, 167-174.

Rebassoo, H.-E. 1967. Hiiumaa floora ja selle genees. Tallinn.

Saarse, L. 1994. Bottom Deposits of Small Estonian Lakes. Institute of Geology, Estonian Academy of Sciences, Tallinn (in Russian).

Saarse, L. \& Königsson, L.-K. 1992. Holocene environmental changes on the Island of Saaremaa, Estonia. PACT, 37, 97-131.

Sarv, A. 1981. Geochronological subdivision of Holocene bog-lacustrine deposits in the region of the Kõivasoo swamp (Hiiumaa island, Estonia). Proc. Acad. Sci. ESSR. Geol., 30, 4, 173178 (in Russian).

Sarv, A., Pork, M. \& Ilves, E. 1982. Stratigraphy and chronology of lake and bog deposits of the Kõivasoo bog. In Peatland Ecosystems (Masing, V., ed.).Valgus, Tallinn, 148-163.

Sepp, U. 1974. Hiiumaa maastikuline iseloomustus. Valgus, Tallinn.

Sterner, R. 1938. Flora der Insel Öland. A Ph S. IX. Uppsala.

Tiismann, B. 1924. Hiiu saare rannikuluited, nende kinnitamine ja metsastamine. Tartu Ülikooli Metsaosakonna Toimetused, 1.

Troels-Smidt, J. 1955. Characterization of Unconsolidated Sediments. Danm. Geol. Unders., IV. Rakke, 3, 10.

\section{KÕPU POOLSAARE TAIMESTIKU JA MAASTIKU ARENG HOLOTSEENIS, HIIUMAA, EESTI}

\section{Lars-König KÖNIGSSON, Leili SAARSE ja Siim VESKI}

Kõpu poolsaarel asuva Kõivasoo kohta tehti uus, detailne õietolmudiagramm, mis näitab, et holotseeni setete akumulatsioon algas siin pisut pärast lepa levikut ja samaaegselt pärna levikuga. Setete lasuvust illustreerivatel läbilõigetel joonistub välja terrassitaoline pind Kõivasoo ida- ja lõunaosas 24-25 m kõrgusel, mis jääb madalamale Litoriinamere kõrgeimast tasemest selles piirkonnas. Setteprofiili kirjeldus on väga detailne ja järgib Troels-Smidti soovitatut. Kuigi Kõpu poolsaare pinnakatte ülaosas valdavad peamiselt liivakad setted, on Kõivasoo setteprofiilis liivaseid kihte suhteliselt vähe. Liivasem ja süttsisaldav kiht 125,5-126,5 $\mathrm{cm}$ sügavusel on tekkinud umbes 4400 aastat tagasi ja langeb 
hästi kokku puusöekõvera järsu tõusuga, tähistades seega kas inimtegevuse ulatuse kiiret laienemist või tõenäolisemalt metsa ja raba põlengut. Selle tagajärjel tekkinud tuiskliiv on kandunud ka soosetetesse.

Ôietolmuanalüüsi tulemused on esitatud täieliku ja kombineeritud diagrammi kujul. Kultuurmaastikku iseloomustavaid liike on suhteliselt vähe. Väga kõnekas on puusöekõver, mis esmakordselt tõuseb hilisboreaalis. Tal on rida väiksemaid tippe atlantikumis, üks markantne tipp subboreaali alguses ning teine selle lõpul. Subatlantikumis on söe kõver praktiliselt pidev, kuid väga varieeruv. Söe maksimum langeb kokku selliste taimede õietolmu hulga suurenemisega nagu Chenopodiaceae, Asteraceae tubuliflorae, Pteridium ja Urtica, mis võisid kasvada mesoliitikumi asulakohtades või nende lähistel.

\section{РАЗВИТИЕ РАСТИТЕЛЬНОСТИ И ЛАНДШАФТА НА ПОЛУОСТРОВЕ КЫПУ В ГОЛОЩЕНЕ, ОСТРОВ СААРЕМАА, эСТОНИЯ}

\section{Ларс-Кёниг КЁНИГССОН, ЛейЛи СААРСЕ и Сийм ВЕСКИ}

Новая палинологическая диаграмма болотных отложений Кыйвасоо показывает, что накопление здесь голоценовых отложений началось одновременно с иммиграцией ольхи и распространением липы. На геологических профилях вырисовываются террасовидные поверхности на абсолютных отметках 24-25 м ниже ур. м., несколько ниже наивысшего уровня Литоринового моря в этом месте. Детальное описание колонки (№ 9) основывается на рекомендациях Троелс-Смидта. Несмотря на преобладание в верхних слоях полуострова Кыпу песчаных отложений, песчанистые прослойки в профиле Кыйвасоо довольно редки. Один наиболее заметный песчанистый слой с древесным углем в торфе на глубине 125,5-126,5 см сформировался примерно 4400 лет т. н. и хорошо совпадает с приростом кривой угля на палинологической диаграмме, указывая тем самым на то, что лес и болото горели. Оголившиеся в результате пожара пески переносились ветром и оседали на болоте.

Результаты спорово-пыльцевого анализа представлены в виде полной и комбинированной диаграмм. Пыльцы, характеризующей хозяйственную деятельность человека, сравнительно мало. Зато кривая древесного угля весьма выразительна, ее четкие пики приходятся на суббореал и субатлантику. Максимальные содержания угля совпадают с ростом пыльцы ряда антропогенных индикаторов, которые могли расти вблизи мезолитических стоянок. Археологические раскопки последних продолжаются. 